\title{
Article
}

Arq Neuropsiquiatr 2011;69(3):424-430

\section{Clinical and neurophysiological investigation of a large family with dominant Charcot-Marie-Tooth type 2 disease with pyramidal signs}

\author{
Eduardo Luis de Aquino Neves ${ }^{1}$, Fernando Kok ${ }^{2}$
}

\begin{abstract}
Charcot-Marie-Tooth (CMT) disease is a hereditary neuropathy of motor and sensory impairment with distal predominance. Atrophy and weakness of lower limbs are the first signs of the disease. It can be classified, with the aid of electromyography and nerve conduction studies, as demyelinating (CMT1) or axonal (CMT2). Objective: Clinical and neurophysiological investigation of a large multigenerational family with CMT2 with autosomal dominant mode of transmission. Method: Fifty individuals were evaluated and neurophysiological studies performed in 22 patients. Results: Thirty individuals had clinical signs of motor-sensory neuropathy. Babinski sign was present in 14 individuals. Neurophysiological study showed motor-sensory axonal polyneuropathy. Conclusion: The clinical and neurophysiological characteristics of this family does not differ from those observed with other forms of CMT, except for the high prevalence of Babinski sign.
\end{abstract}

Key words: Charcot-Marie-Tooth disease, CMT2, axonal hereditary neuropathy.

Investigação clínica e neurofisiológica de família com doença de Charcot-Marie-Tooth tipo 2 com sinais piramidais

\section{RESUMO}

A doença de Charcot-Marie-Tooth (CMT) é uma neuropatia hereditária de acometimento sensitivo e motor de predomínio distal. Atrofia e fraqueza em membros inferiores são os primeiros sinais da doença. Pode ser classificada, com auxílio da eletroneuromiografia, em desmielinizante (CMT1) ou axonal (CMT2). Objetivo: Investigação clínica e neurofisiológica de família com portadores de CMT2 de herança dominante. Método: Foi feita avaliação neurológica de 50 indivíduos e eletroneuromiografia em 22 pacientes. Resultados: Trinta indivíduos tinham sinais clínicos de neuropatia sensitivo-motora. Sinal de Babinski estava presente em 14 indivíduos. A eletroneuromiografia demonstrou polineuropatia axonal sensitiva e motora. Conclusão: As características clínicas e neurofisiológicas desta família não se diferem das observadas em outras formas de CMT, exceto pela alta prevalência de sinal de Babinski.

Palavras-chave: doença de Charcot-Marie-Tooth, CMT2, neuropatia hereditária axonal.

Charcot-Marie-Tooth (CMT) disease is one of the most common genetically determined neurological disorder, with an estimated prevalence of 37/100,000 individuals ${ }^{1}$. It is characterized by impairment of peripheral nerves function, with distal predominance and a highly variable clinical course.

According to the nature of peripheral nerve injury, CMT disease can be divided into two main groups: demyelinating (CMT1) and axonal (CMT2) $)^{2,3}$. 
Other classifications are based on transmission pattern and genetic basis.

CMT disease causes progressive weakness and atrophy, initially in distal muscles of lower limbs and later reaching the upper limbs, with foot deformities, loss of sensitivity, and reduced tendon reflexes ${ }^{3}$.

Especially among individuals affected by demyelinating neuropathy (CMT1), it is frequent to find atrophy of the distal third of the legs, giving the appearance of an inverted champagne glass and of pes cavus. The proximal muscles are rarely affected ${ }^{3}$. Cranial nerve involvement is rare, but there are descriptions of families with vocal cord paresis and deafness associated with $\mathrm{CMT}^{4,5}$. Reduction and even abolition of the reflexes are the rule, although in some forms of CMT it is possible to find brisk reflexes and even the presence of Babinski sign ${ }^{3,4,6-8}$.

It is not common for individuals with CMT to present subjective sensory symptoms or neuropathic pain ${ }^{9}$. The sensory abnormalities are primarily due to a more pronounced loss of myelinated thick fibers $(\mathrm{A} \alpha)^{1}$. Sense for vibration and pain are the first to be changed.

More rarely, additional signs can be found such as action tremor, optic atrophy, deafness, pupillary abnormalities, and foot ulcers ${ }^{4,10}$. In some individuals and families, pyramidal signs, as brisk tendon reflexes and Babinski sign, without spasticity, might be detected ${ }^{3,4,8,10}$.

Electromyography (EMG) and nerve conduction studies (NCS) allow differentiation of demyelinating (CMT1) from axonal (CMT2) neuropathies: in the first, the conduction velocity is less than $38 \mathrm{~m} / \mathrm{s}$, while in the second it is over $38 \mathrm{~m} / \mathrm{s}^{2,3,11-14}$. There are also intermediate forms, with motor conduction velocities of the median between 30 and $40 \mathrm{~m} / \mathrm{s}^{15}$.

According to the type of inheritance, CMT 1 is of autosomal dominant inheritance, and CMT2 is transmitted as a dominant or recessive character ${ }^{1,4,16}$. The forms of inheritance linked to the X are known as CMTX, and the autosomal-recessive demyelinating forms are called CMT4. CMT5 is used to refer to CMT with spasticity.

For CMT1, five loci and the genes associated with them have been located and identified: about 70 to $80 \%$ of cases are caused by duplication of the PMP22 gene, and 5 to $10 \%$ are caused by mutation in the $M P Z$ gene $^{1}$.

To date, 13 loci are known to be associated with CMT2, and only 9 genes have been identified so far ${ }^{4,17}$. Four of the 13 loci are related to forms of recessive inheritance and some have been identified in only one family. CMT 2A is the most prevalent form of axonal CMT, being responsible for approximately $20 \%$ of axonal $\mathrm{CMT}^{17}$. It is caused by mutation of the MFN2 gene, located on the $1 \mathrm{p} 36$ chromosome, which encodes the GTPase mitofusin, involved in mitochondrial fusion ${ }^{4,17}$.

This study aims to investigate, from the clinical, neu- rophysiological, and genetic point of view, a family living in the municipality of Tobias Barreto, situated $180 \mathrm{~km}$ from Aracaju, Sergipe State, Brazil.

\section{METHOD \\ Clinical evaluation}

After completion of the heredogram and identification of possible individuals affected by CMT among family members, a clinical neurological evaluation was performed. All participants of the study signed a consent form, approved by the Institutional Committee for Ethics in Research.

\section{Neurophysiological studies}

EMG was performed using Viking Quest (Nicolet) 9.0 equipment. The records were obtained following a conventional protocol as reported by Oh and cols. ${ }^{18}$, surface electrodes and stimulator were used for NCS. The action potentials amplitudes for motor nerves were measured from the peak of the negative wave to the baseline, and for sensory nerves from peak-to-peak. Temperature were controlled, and never less than $33^{\circ} \mathrm{C}$.

\section{Application of the Charcot-Marie-Tooth Neuropathy Score}

The Charcot-Marie-Tooth Neuropathy Score (CMTNS), developed by Shy and cols. ${ }^{19}$ were used to assess disease severity. This score combines motor and sensory manifestations with data obtained from NCS. The maximum possible score is of 36 points and patients with less than 10 points are classified as mildly affected, with between 11 and 20 points as moderately compromised and with more than 21 points as severely affected ${ }^{19}$.

\section{RESULTS}

Thirth-five individuals with CMT were recognized, and 30 completed clinical evaluation which allows inclusion in this study. Age at ascertainment varied from 3 to 75 years, and age of onset varied greatly. Four patients with abnormal findings at clinical examination did not have complaints. Frequent falls was the the first recognized abnormality in cases with onset at childhood. In adolescents and adults, inability to run was usually seen as an early manifestation. Neuropathic pain was never reported.

This family presents a form of CMT with autosomal dominant transmission, as can be observed in the heredogram (Figure). The presence of father-to-child transmission excludes an X-linked transmission.

Neurological exam - The clinical findings are summarized in Table 1. All the patients were able to walk without assistance, except patients III-10 and III-41, who already had significant impairment of gait and could only 


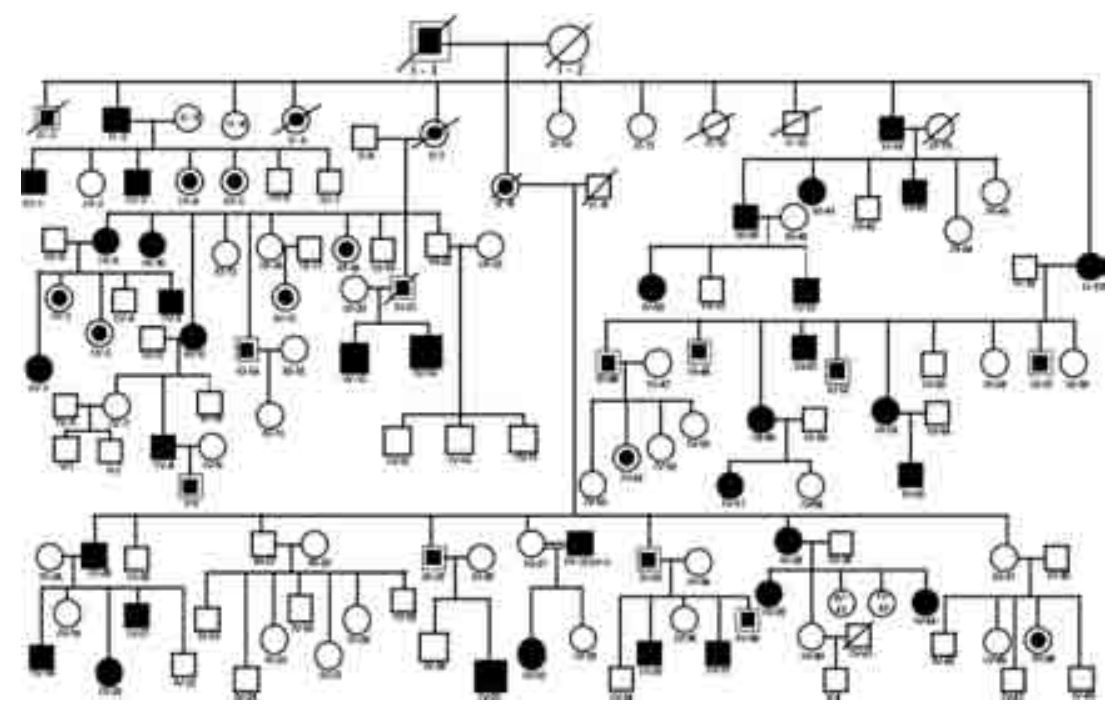

Filled symbols: affected individuals; Open symbols: unaffected individuals; Squares: men; Circles: woman; Shaded symbols: probably affected; Slashed symbols: deceased individuals; CMT2: Charcot-Marie-Tooth type 2.

Figure. Heredogram of family with CMT 2.

Table 1. Clinical data of CMT2 family.

\begin{tabular}{|c|c|c|c|c|c|c|c|c|c|}
\hline Patient & $\begin{array}{c}\text { Age } \\
\text { (years) }\end{array}$ & $\begin{array}{l}\text { Onset } \\
\text { (years) }\end{array}$ & Ambulation & Atrophy & Pes cavus & $\begin{array}{l}\text { Babinski } \\
\text { sign }\end{array}$ & $\begin{array}{c}\text { Tibialis anterior } \\
\text { weakness }\end{array}$ & $\begin{array}{l}\text { Achilles } \\
\text { reflex }\end{array}$ & Sensitivity* \\
\hline$\| 1-2$ & 75 & 40 & yes & no & no & & no & present & reduced \\
\hline II-14 & 74 & 53 & yes & legs and hands & yes & & yes & absent & reduced \\
\hline III-9 & 46 & 14 & yes & hands and legs & yes & & yes & absent & reduced \\
\hline |II-10 & 48 & 12 & no & legs and hands & no & bilateral & yes & exalted & reduced \\
\hline|| $\mid-12$ & 51 & 10 & yes & hands and feet & no & & yes & absent & reduced \\
\hline |||-14 & 36 & 14 & yes & forearms and legs & yes & & yes & present & reduced \\
\hline III-25 & 47 & 30 & yes & hands and feet & no & & yes & present & reduced \\
\hline III-35 & 41 & 30 & yes & hands and feet & no & bilateral & yes & present & reduced \\
\hline |11-39 & 44 & 16 & yes & legs & yes & & yes & absent & reduced \\
\hline|| $\mid-41$ & 45 & 7 & with aid & legs and hands & yes & & yes & absent & reduced \\
\hline |||-49 & 43 & 37 & yes & no & no & & yes & present & reduced \\
\hline |II-51 & 37 & 5 & yes & no & yes & & yes & brisk & reduced \\
\hline IV-1 & 23 & 15 & yes & no & yes & & yes & present & reduced \\
\hline IV-5 & 18 & 13 & yes & hands and legs & yes & bilateral & yes & absent & reduced \\
\hline IV-8 & 28 & 9 & yes & legs & yes & & yes & absent & reduced \\
\hline IV-13 & 13 & 5 & yes & feet and hands & yes & bilateral & yes & absent & reduced \\
\hline IV-14 & 12 & 7 & yes & legs and hands & no & right & yes & absent & reduced \\
\hline IV -18 & 19 & 19 & yes & no & yes & right & yes & present & reduced \\
\hline IV-20 & 13 & 8 & yes & hands and legs & yes & bilateral & yes & present & reduced \\
\hline IV-31 & 11 & 9 & yes & legs & yes & & yes & absent & reduced \\
\hline IV-32 & 16 & 10 & yes & legs & yes & bilateral & yes & present & reduced \\
\hline IV-39 & 7 & 6 & yes & hands and feet & yes & left & yes & present & reduced \\
\hline IV-44 & 11 & 6 & yes & legs and hands & yes & bilateral & yes & brisk & reduced \\
\hline IV-50 & 13 & 6 & yes & legs and hands & yes & bilateral & yes & brisk & reduced \\
\hline IV-52 & 11 & 8 & yes & legs and hands & yes & bilateral & yes & absent & reduced \\
\hline IV- 54 & 20 & 7 & yes & feet and hands & yes & & yes & absent & reduced \\
\hline IV-57 & 14 & 12 & yes & hands and feet & yes & right & yes & present & reduced \\
\hline IV-59 & 10 & 5 & yes & hands and feet & yes & left & yes & present & reduced \\
\hline$V-3$ & 6 & 3 & yes & no & no & & no & absent & \\
\hline$V-4$ & 3 & 3 & yes & no & no & & yes & present & \\
\hline
\end{tabular}

TA: tibialis anterior; CMT2: Charcot-Marie-Tooth type 2; ${ }^{*}$ Sensitivity surface-painful (pinprick) and deep-vibration. 
Table 2. Neurophysiological data of patients with CMT 2.

\begin{tabular}{|c|c|c|c|c|c|c|c|c|c|c|}
\hline Patient & Age & Side R/L & $\begin{array}{l}\text { Median } \\
\text { motor } \\
\text { amp. / CV }\end{array}$ & $\begin{array}{c}\text { Ulnar } \\
\text { motor } \\
\text { amp. / CV }\end{array}$ & $\begin{array}{l}\text { Peroneal } \\
\text { motor } \\
\text { amp. / CV }\end{array}$ & $\begin{array}{l}\text { Tibialis } \\
\text { motor } \\
\text { amp. / CV }\end{array}$ & $\begin{array}{c}\text { Median } \\
\text { sensory } \\
\text { amp. / CV }\end{array}$ & $\begin{array}{c}\text { Ulnar } \\
\text { sensory } \\
\text { amp. / CV }\end{array}$ & $\begin{array}{c}\text { Sural } \\
\text { sensory } \\
\text { amp. / CV }\end{array}$ & $\begin{array}{c}\text { Wave-F } \\
\text { ulnar }\end{array}$ \\
\hline II-14 & 73 & $\begin{array}{l}D \\
E\end{array}$ & $\begin{array}{l}\text { Unrecor. } \\
\text { Unrecor. }\end{array}$ & $3.7 / 56$ & $\begin{array}{l}\text { Unrecor. } \\
\text { Unrecor. }\end{array}$ & $\begin{array}{l}\text { Unrecor. } \\
\text { Unrecor. }\end{array}$ & $6.1 / 48$ & $\begin{array}{l}\text { NO } \\
\text { NO }\end{array}$ & $\begin{array}{l}\text { NO } \\
\text { NO }\end{array}$ & 28.9 \\
\hline |II-14 & 36 & $\begin{array}{l}D \\
E\end{array}$ & & $1.2 / 58$ & $\begin{array}{l}\text { Unrecor. } \\
\text { Unrecor. }\end{array}$ & $\begin{array}{l}\text { Unrecor. } \\
\text { Unrecor. }\end{array}$ & & $4 / 51$ & $\begin{array}{l}4.0 \text { / } 47 \\
3.0 / 43\end{array}$ & \\
\hline |II-25 & 47 & $\begin{array}{l}D \\
E\end{array}$ & Unrecor. & $5.0 / 51$ & $\begin{array}{l}1.5 / 45 \\
0.4 \text { / } 37\end{array}$ & $\begin{array}{l}1.1 / 47 \\
0.9 / 49\end{array}$ & $13 / 54$ & NO & $\begin{array}{l}4.0 / 45 \\
3.0 / 51\end{array}$ & 29.8 \\
\hline III-35 & 41 & $\begin{array}{l}D \\
E\end{array}$ & $1.1 / 50$ & & $\begin{array}{l}1.4 / 49 \\
0.6 / 52\end{array}$ & $\begin{array}{l}5.7 / 41 \\
2.4 / 48\end{array}$ & $33 / 61$ & & $\begin{array}{l}3.0 / 48 \\
3.0 / 44\end{array}$ & \\
\hline |||-41 & 41 & $\begin{array}{l}D \\
E\end{array}$ & $\begin{array}{l}\text { Unrecor. } \\
\text { Unrecor. }\end{array}$ & $\begin{array}{l}1.8 / 52 \\
2.7 / 39\end{array}$ & $\begin{array}{l}\text { Unrecor. } \\
\text { Unrecor. }\end{array}$ & $\begin{array}{l}\text { Unrecor. } \\
\text { Unrecor. }\end{array}$ & $\begin{array}{l}14 / 53 \\
26 / 52\end{array}$ & $\begin{array}{l}7.0 \text { / } 56 \\
9.0 \text { / } 57\end{array}$ & $\begin{array}{l}2.0 / 46 \\
2.0 / 42\end{array}$ & 30.3 \\
\hline |||-49 & 43 & $\begin{array}{l}D \\
E\end{array}$ & $6.5 / 53$ & 8.2 / 61 & $\begin{array}{l}3.6 / 36 \\
3.8 / 34\end{array}$ & $\begin{array}{l}5.1 / 46 \\
4.5 / 44\end{array}$ & & $18 / 54$ & $\begin{array}{c}4.0 / 44 \\
\text { NO }\end{array}$ & \\
\hline IV-5 & 18 & $\begin{array}{l}D \\
E\end{array}$ & Unrecor. & $7.2 / 58$ & $\begin{array}{l}0.9 / 35 \\
0.2 / 32\end{array}$ & $\begin{array}{l}1.5 / 37 \\
0.9 / 43\end{array}$ & & $4.0 / 58$ & $\begin{array}{l}\text { NO } \\
\text { NO }\end{array}$ & \\
\hline IV-8 & 28 & $\begin{array}{l}D \\
E\end{array}$ & $\begin{array}{l}\text { Unrecor. } \\
\text { Unrecor. }\end{array}$ & $0.4 / 46$ & $\begin{array}{l}\text { Unrecor. } \\
\text { Unrecor. }\end{array}$ & $\begin{array}{l}\text { Unrecor. } \\
\text { Unrecor. }\end{array}$ & $\begin{array}{l}\text { NO } \\
\text { NO }\end{array}$ & & $\begin{array}{l}2.5 / 43 \\
2.6 / 39\end{array}$ & \\
\hline IV-13 & 13 & $\begin{array}{l}D \\
E\end{array}$ & Unrecor & $0.2 / 46$ & $\begin{array}{l}0.6 / 43 \\
0.9 / 41\end{array}$ & $\begin{array}{l}0.3 / 49 \\
0.3 / 37\end{array}$ & NO & NO & $\begin{array}{l}2.3 / 44 \\
2.6 / 49\end{array}$ & \\
\hline IV-14 & 12 & $\begin{array}{l}D \\
E\end{array}$ & $0.2 / 46$ & & $\begin{array}{l}0.8 \text { / } 47 \\
0.1 / 45\end{array}$ & $\begin{array}{l}1.5 / 49 \\
2.1 / 41\end{array}$ & NO & & $\begin{array}{l}3.6 / 45 \\
3.0 / 52\end{array}$ & \\
\hline IV-18 & 19 & $\begin{array}{l}D \\
E\end{array}$ & 9.9 / 56 & & $\begin{array}{l}2.1 / 45 \\
1.4 / 40\end{array}$ & $\begin{array}{l}11.1 / 50 \\
15.1 / 51\end{array}$ & $12 / 53$ & 7 / 47 & $\begin{array}{l}7.0 \text { / } 47 \\
8.0 \text { / } 46\end{array}$ & \\
\hline IV-20 & 13 & $\begin{array}{l}D \\
E\end{array}$ & $\begin{array}{c}0.2 / \\
2.6 / 50\end{array}$ & $2.4 / 54$ & $\begin{array}{l}4.2 / 45 \\
3.0 / 45\end{array}$ & $\begin{array}{l}4.0 / 43 \\
5.5 / 43\end{array}$ & $43 / 50$ & $36 / 61$ & $\begin{array}{l}2.4 / 40 \\
1.5 / 40\end{array}$ & $\begin{array}{l}32.8 \\
31.8\end{array}$ \\
\hline IV-31 & 11 & $\begin{array}{l}D \\
E\end{array}$ & $4.3 / 53$ & & $\begin{array}{l}2.1 / 45 \\
2.1 / 44\end{array}$ & $\begin{array}{l}12.2 / 48 \\
10.0 / 48\end{array}$ & & & $\begin{array}{l}7.0 / 46 \\
4.6 / 50\end{array}$ & \\
\hline IV-32 & 15 & $\begin{array}{l}D \\
E\end{array}$ & & & $\begin{array}{l}1.9 / 46 \\
1.7 / 49\end{array}$ & $\begin{array}{l}7.5 / 43 \\
8.2 / 41\end{array}$ & & & $\begin{array}{c}10.2 \text { / } 47 \\
9.6 / 42\end{array}$ & \\
\hline IV-39 & 7 & $\begin{array}{l}D \\
E\end{array}$ & & $5.8 / 58$ & $\begin{array}{l}3.1 / 52 \\
4.1 / 48\end{array}$ & $\begin{array}{l}6.2 / 47 \\
7.4 / 58\end{array}$ & & $20 / 52$ & $\begin{array}{l}14.0 / 50 \\
12.0 / 44\end{array}$ & \\
\hline IV-44 & 16 & $\begin{array}{l}D \\
E\end{array}$ & Unrecor. & Unrecor. & $\begin{array}{l}2.0 \text { / } 40 \\
\text { Unrecor. }\end{array}$ & $\begin{array}{l}2.2 \text { / } 45 \\
3.3 / 45\end{array}$ & & 1.9 / 47 & $\begin{array}{l}6.0 / 53 \\
4.0 / 48\end{array}$ & \\
\hline IV-50 & 12 & $\begin{array}{l}D \\
E\end{array}$ & $3.6 / 56$ & & $\begin{array}{l}1.2 \text { / } 37 \\
2.5 / 44\end{array}$ & $\begin{array}{l}6.8 / 40 \\
6.6 / 45\end{array}$ & NO & $23 / 53$ & $\begin{array}{l}13.0 / 43 \\
12.1 / 43\end{array}$ & \\
\hline IV-52 & 10 & $\begin{array}{l}D \\
E\end{array}$ & & & $\begin{array}{l}1.3 / 40 \\
1.2 / 40\end{array}$ & $\begin{array}{l}2.3 / 42 \\
1.9 / 40\end{array}$ & & & $\begin{array}{l}5.1 / 42 \\
6.2 / 43\end{array}$ & \\
\hline IV-54 & 20 & $\begin{array}{l}D \\
E\end{array}$ & & $2.0 / 52$ & $\begin{array}{c}0.1 \text { / } 37 \\
\text { Unrecor. }\end{array}$ & $\begin{array}{l}3.0 \text { / } 39 \\
1.3 / 38\end{array}$ & $29 / 48$ & $20 / 48$ & $\begin{array}{l}8.0 \text { / } 42 \\
7.0 \text { / } 42\end{array}$ & \\
\hline IV-57 & 14 & $\begin{array}{l}D \\
E\end{array}$ & $0.2 / 53$ & $1.9 / 63$ & $\begin{array}{l}\text { Unrecor } \\
0.6 \text { / } 37\end{array}$ & $\begin{array}{l}4.5 / 43 \\
2.4 / 36\end{array}$ & & $11 / 54$ & $\begin{array}{l}6.0 / 50 \\
8.0 / 47\end{array}$ & \\
\hline IV-59 & 9 & $\begin{array}{l}D \\
E\end{array}$ & $5.1 / 51$ & & $\begin{array}{l}1.4 / 42 \\
1.6 / 40\end{array}$ & $\begin{array}{l}9.4 / 48 \\
9.1 / 46\end{array}$ & & & $\begin{array}{l}5.4 / 41 \\
5.6 / 40\end{array}$ & \\
\hline$V-3$ & 6 & $\begin{array}{l}D \\
E\end{array}$ & & & $\begin{array}{l}1.9 / 45 \\
2.1 / 41\end{array}$ & $\begin{array}{l}10.2 / 43 \\
10.8 / 43\end{array}$ & & & $\begin{array}{l}8.0 / 50 \\
8.2 \text { / } 50\end{array}$ & \\
\hline
\end{tabular}

Reference values: Dumitru, 199511. Amp.: amplitude; VC: velocity of conduction; L: left; R: right; NO: not obtained; Unrecord.: unrecordable; CMT 2: CharcotMarie-Tooth type 2. Abnormal values in bold. 
ambulate with an walker. The siblings IV-13 and IV-14 had a very unstable gait, but could walk without assistance; they are nephews of patient III-10, and all affect individuals in this branch of the kindred had a more severe form of CMT, associated with pyramidal signs.

Pyramidal signs, characterized by the presence of Babinski sign with or without brisk reflexes, was present in 14 patients. None of the subjects presented spasticity. Lower limbs atrophy was seen in 23 patients (76\%) and hands atrophy in 19 individuals (63\%). The atrophy was restricted to the distal third of the legs and to the hands, except for patients III-10, III-14, IV-8, IV-44, IV-52, IV57 , and II-14, who also had forearm atrophy, and patients IV-13 and IV-14, who had forearms and arms atrophy. Pes cavus was present in 21 patients (70\%) and flat feet were observed in six individuals. Paresis of the tibialis anterior was the most consistent clinical abnormality, present in 28 patients (93\%). In all patients, with exception of individuals V-4 and V-3, who where too young to give consistent answers, a reduction of superficial and deep sensitivity in the distal portions of the lower limbs were detected. Pain and vibration hypoesthesia were also detected in fingers of 10 patients. Thirteen individual had bilateral abolition of the Achilles reflexes and four patients (IV-44, III- 51, IV-50, and III-10) presented brisk reflexes. Seven patients (IV-13, IV-14, IV-44, IV-5, IV-57, III-14, and III-10) had brisk patellar reflexes .

Neurophysiological studies - EMG and NCS were performed in 22 individuals and the data obtained are summarized in Table 2. All 22 patients had neurophysiological changes consistent with predominantly motor axonal neuropathy and greater distal involvement, except for patient IV-39. The most consistent neurophysiological finding was reduced amplitudes of compound motor action potentials of the motor nerves (CMAPs). The peroneal nerves showed the greatest reductions in CMAPs. Motor conduction velocity was slightly reduced in only 10 of the 22 patients. The lowest conduction velocity of the median nerve was $46 \mathrm{~m} / \mathrm{s}$. In the study of sensory conduction, a reduction of the amplitudes of sen- sory nerve action potentials (SNAPs) was also the most common finding, especially in the sural nerves. EMG with concentric needle proved to be abnormal in the 12 patients in which it was performed. The most consistent finding was reduction in the recruitment pattern of motor units, seen in the short extensor muscles of the fingers and tibialis anterior.

CMTNS application - The CMTNS was applied in 21 patients and results can be seen in Tables 3 and 4. The

Table 3. Charcot-Marie-Tooth Neuropathy Score in 21 patients with CMT2.

\begin{tabular}{|c|c|c|c|}
\hline Patient & Age & Score & $\begin{array}{c}\text { Duration of } \\
\text { disease (years) }\end{array}$ \\
\hline II-14 & 75 & 18 & 35 \\
\hline|| $\mid-10$ & 48 & 26 & 36 \\
\hline |||-14 & 36 & 22 & 22 \\
\hline |II-25 & 47 & 16 & 17 \\
\hline |II-35 & 41 & 12 & 11 \\
\hline |||-41 & 45 & 21 & 37 \\
\hline |||-49 & 43 & 6 & 6 \\
\hline IV-5 & 18 & 13 & 5 \\
\hline IV-8 & 28 & 16 & 19 \\
\hline IV-13 & 13 & 25 & 8 \\
\hline IV-14 & 12 & 23 & 5 \\
\hline IV-18 & 19 & 11 & Not known \\
\hline IV-20 & 13 & 12 & 5 \\
\hline IV-32 & 16 & 9 & 6 \\
\hline IV-39 & 7 & 6 & 1 \\
\hline IV-44 & 11 & 17 & 5 \\
\hline IV-50 & 13 & 11 & 7 \\
\hline IV-52 & 11 & 14 & 3 \\
\hline IV-54 & 20 & 10 & 13 \\
\hline IV-57 & 14 & 14 & 2 \\
\hline IV-59 & 10 & 9 & 5 \\
\hline
\end{tabular}

Mean age: 25.6 years; Average score: 14.8 points; CMT 2: Charcot-MarieTooth type 2.

Table 4. Disease duration and Charcot-Marie-Tooth Neuropathy Score.

\begin{tabular}{lcccc} 
& Generation II & Generation III & Generation IV & Gereration V \\
\hline Number of patients & 2 & 10 & 16 & 2 \\
Mean age & & 43.33 years & 14.63 years \\
Age range & & 36 to 48 years & 7 to 28 years & 3 years \\
Mean age of onset & 46.5 years & 17.5 years & 9.06 years & 3 years \\
Range of age of onset & 40 to 50 years & 5 to 37 years & 5 to 19 years & 7 years \\
Mean duration of disase & & 21.5 years & 13.91 & 6 to 25 \\
CMTNS mean & & 17.16 & 6 to 26 & \\
CMTNS range & & &
\end{tabular}


patients showed variation from 6 to 26 points. Five were mildly affected (score up to 10), 11 were moderately compromised (score between 11 and 20), and five had a severe compromise (score $>21$ ). The mean score in generation III was 17.16 points (range 6 to 26 points). In generation IV, the mean was 13.9 points (range 6 to 25 points).

\section{DISCUSSION}

In the last two decades several loci and genes related to CMT2 have been recognized ${ }^{20}$. We conducted a clinical and neurophysiological study of a multigenerational family with 35 individuals affected by an autosomal dominant form of CMT2, which is probably the largest kindred ever reported in Brazil.

Thirty individuals with CMT from completed the clinical study. We observed an earlier onset and larger severity of the disease at later generations, a fact already observed by other authors ${ }^{21-23}$. Assessment of disease severity by CMTNS shows that ten individuals of generation IV already have high scores. Generation IV, with a mean of 7 years of disease, has in the CMTNS a mean of 13.9 points (moderate incapacity). In generation III, with a mean of 21.5 years of disease, CMTNS mean scorer was of 17.1 points. This finding could be a result of an ascertainment bias, caused by an increased awareness about the disease. The assessment of individuals of generations V and VI might help establish this issue.

Neuropathic pain and other positive sensory symptoms have not been fully investigated in most families studies of $\mathrm{CMT}^{1}$. Germignani et al. ${ }^{9}$, showed that approximately $71 \%$ of the individuals had positive sensory symptoms, including neuropathic pain. In contrary, none of the individuals evaluated in this family complained of neuropathic pain. When present, sensory complaints were most often consistent with late onset nociceptive pain, and probably arising from osteo-muscular deformities. as suggested by Padua et al. ${ }^{24}$.

Trophic changes seen in the feet, legs, and hands of individuals from this family are typical of CMT disease. The presence of pes cavus, so characteristic of CMT disease, was absent in one-third of the patients.

In some individuals, tendon reflexes were abolished and in others were brisk. The presence of pyramidal signs, with Babinski sign and hyperreflexia seen in several individuals of this family, has been described in other families with $\mathrm{CMT}^{3,8,25,26}$. What differentiates CMT2 with pyramidal signs from CMT V (or HMSN V) is the obligate presence of spasticity in the latter. Vucci et cols. found CMT with pyramidal signs in $9 \%$ of the families that they have studied, and demonstrated that the presence of CMT with Babinski sign was genetically distinct from all known forms of $\mathrm{CMT}^{26}$. In the present family, we observed pyramidal signs in $46 \%$ of the individuals.
Those individual had usually higher scores at CMTNS, which could not be explained by central nervous system involvement, but probably by a more marked progression of atrophy, affecting proximal muscles of the upper and lower limbs.

The neurophysiological study was consistent with an axonal motor-sensory neuropathy. Reduction of the amplitudes of motor action potentials in peroneal nerves was the earlier and more frequent finding. This study showed no singularities when compared to other families with CMT2, but provided information allowed determination of CMTNS, which allowed rating severity of disease. The CMTNS seeks to assess precisely the axonal loss that the disease eventually determines over time in both the distal and proximal upper and lower limbs.. The application of the score is fast and able to be held in all locations where the clinical neurological evaluation and neuroconduction study can be done, with no need for more sophisticated equipment, such as quantitative sensory testing (QST).

To conclude, in this study, we studied 30 individuals of a multigenerational family with autosomal dominant CMT2, which was associated in $46 \%$ of cases with pyramidal signs. Neurophysiological study was typical of an axonal compromise. It was also remarkable that disease severity was higher and age of symptoms onset earlier in the more recent generation. A genetic study is underway to better characterize the molecular basis of this condition.

\section{REFERENCES}

1. Klein CJ, Dyck PJ. HMSN II (CMT2) and miscellaneous inherited system atrophies of nerve axon: clinical-molecular genetic correlates. In: Dyck PJ, Thomas PK (Eds). Peripheral Neuropathy. Fourth Edittion. Philadelphia: Elsevier Saunders, 2005:1717-1752.

2. Davis CJF, Bradley WG, Madrid R. The peroneal muscular atrophy syndrome: clinical, genetic, electrophysiological and nerve biopsy findings and classification. J Genet Hum 1978;26:311-349.

3. Harding AE, Thomas PK. The clinical features of hereditary motor and sensory neuropathy types I and II. Brain 1980; 103: 259-280.

4. Barisic N, Claeys KG, Sirotkovic-Skerlev M, et al. Charcot-Marie-Tooth disease: a clinic-genetic confrontation. Ann Hum Genet 2008;2:416-441.

5. Verhoeven K, Claeys KG, Züchner S, et al. MFN2 mutation distribution and genotype/phenotype correlation in Charcot-Marie-Tooth type 2. Brain 2006; 129:2093-2102.

6. Chung KW, Kim SB, Park KD, et al. Early onset severe and late-onset mild Charcot-Marie-Tooth disease with mitofusin 2 (MFN2) mutations. Brain 2006;129:2103-2118.

7. Bienfait HME, Baas F, Koelman JHTM, et al. Phenotype of Charcot-MarieTooth type 2. Neurology 2007;68:1658-1667.

8. Zhu D, Kennerson ML, Walizada G, Züchner S, Vance JM, Nicholson GA. Charcot-Marie-Tooth with pyramidal signs is genetically heterogeneous: families with and without MFN2 mutations. Neurology 2005;65:496-497.

9. Gemignani F, Melli G, Alfieri S, Inglese C, Marbini A. Sensory manifestations in Charcot-Marie-Tooth disease. J Peripher Nerv Syst 2004;9:7-14.

10. Lawson VH, Graham BV, Flanigan KM. Clinical and electrophysiologic features of CMT2A with mutations in the mitofusin 2 gene. Neurology 2005; 65:197-204.

11. Dumitru D. Generalized peripheral neuropathies. In: Demitru D (Ed). Electrodiagnostic medicine. Philadelphia. Hanley \& Belfus 1995:741-848.

12. Engelfried $K$, Vorgerd M, Hagedorn M, et al. Charcot-Marie-Tooth neu- 
ropathy type 2A: novel mutations in the mitofusin 2 gene (MFN2). BMC Med Genet 2006;7:53.

13. Kimura J. Electrodiagnosis in diseases of nerve and muscle: principles and pratice. Ed. 3. Oxford University Press, 2001.

14. Muglia M, Zappia M, Timmerman V, et al. Clinical and genetic study of

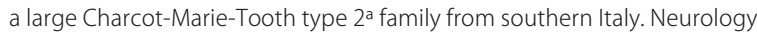
2001:56:100-103.

15. Sevilla T, Jaijo T, Nauffal D, et al. Vocal cord paresis and diaphragmatic dysfunction are severe and frequent symptoms of GDAP1-associated neuropathy. Brain 2008;131:3051-3061.

16. Harding AE, Thomas PK. Genetic aspects of hereditary motor and sensory neuropathy (types I and II). J Med Genet 1980;17:329-336.

17. Züchner S, Vance JM. Molecular genetics of autosomal-dominant axonal Charcot-Marie-Tooth disease. Neuromolecular Med 2006;8:63-74.

18. Oh J. Clinical electromyography: nerve conduction studies. $2^{\text {nd }}$ Ed. Williams \& Wilkins, Baltimore 1993.

19. Shy ME, Blake J, Krajewski K, et al. Reliability and validity of the CMT neuropathy score as a measure of disability. Neurology 2005;64:1209-1214.
20. Nicholson GA. The dominantly inherited motor and sensory neuropathies: clinical and molecular advances. Muscle Nerve 2006;33:589-597.

21. Kovach MJ, Campbell KC, Herman K, et al. Anticipation in a unique family with Charcot-Marie-Tooth syndrome and deafness: delineation of the clinical features and review of the literature. Am J Med Genet 2002;108:295-303.

22. Steiner I, Gotkine M, Steiner-Birmanns B, et al. Increased severity over generations of Charcot-Marie-Tooth disease type 1A. J Neurol 2008;255:813-819.

23. Marques W, Hanna MG, Marques SR, Sweeney MG, Thomas PK, Wood NW. Phenotypic variation of a new PO mutation in genetically identical twins. J Neurol 1999;246:596-599.

24. Padua L, Cavallaro T, Pareyson D, Quattrone A, Vita G, Schenone A+ Italian CMT QoL Study Group. Charcot-Marie-Thooth and pain: correlations with neurophysiological, clinical, and disability findings. Neurol Sci 2008;29: 193-194.

25. Gemignani F, Marbini A. Charcot-Marie-Tooth disease (CMT): distinctive phenotypic and genotypic features in CMT type 2. J Neurol Sci 2001;184:1-9.

26. Vucic S, Kennerson M, Zhu D, Miedema E, Kok C, Nicholson GA. CMT with pyramidal features Charcot-Marie-Tooth. Neurology 2003;60:696-699. 